\section{JOANNA LUSTAŃSKI}

McMaster University, Kanada

https://orcid.org/0000-0002-9346-364X
Copyright and License: Copyright by Instytut Języka Polskiego PAN, Kraków 2021. This article is published under the terms of the Creative Commons Attribution - NoDerivatives 4.0 International (CC BY- ND 4.0) License (https:// creativecommons.org/licenses/by-nd/4.0/legalcode.pl).

\title{
WYMIARY POTOCZNEJ ŚWIADOMOŚCI JĘZYKOWEJ I RELACJE MIĘDZY NIMI
}

Słowa kluczowe: potoczna świadomość językowa, wyznaczniki świadomości, lingwistyka potoczna, postawy językowe, Polonia kanadyjska.

\section{STRESZCZENIE}

Niniejszy artykuł przedstawia wyznaczniki tzw. potocznej świadomości językowej według koncepcji Dennisa R. Prestona, który jako pierwszy wprowadził je do amerykańskiej szkoły lingwistyki potocznej w latach 90 . ubiegłego wieku. Wyróżniki te to: eksplicytna dostępność zakresu zjawisk językowych podlegających ocenie, stopień trafności tej oceny, poziom jej szczegółowości oraz umiejętność kontrolowania różnych wariantów języka. Zasadniczą cechą tych wykładników jest to, że - w odróżnieniu od typowych narzędzi do badań nad świadomością językową, które analizują warstwy i poziomy świadomości - pozwalają one na badanie sposobów, w jakie ujawnia się świadomość przeciętnego użytkownika języka, tzw. językoznawczego laika. W rodzimych badaniach fenomenu świadomości językowej wyznaczniki te nie były dotychczas opisywane i wykorzystywane, chociaż prezentują nowe możliwości eksplikacji badawczej. W niniejszym artykule do charakterystyki koncepcji Dennisa R. Prestona posłużono się częściowo przykładami użytymi przez samego badacza, a częściowo odwołano się do przykładów porównywalnych, ale pochodzących ze źródeł rodzimych, w tym egzemplifikacji językowych ekscerpowanych wśród polskiej grupy etnicznej w Kanadzie. W artykule przedstawiono również relacje między wyznacznikami potocznej świadomości językowej, które zilustrowano w sposób graficzny. Wstępna diagnoza dotycząca zdatności charakteryzowanych wyróżników w studiach nad świadomością językową użytkowników polszczyzny zachęca do pogłębionych analiz, w jakiej mierze te - względnie zobiektywizowanie - narzędzia mogą okazać się przydatne do badań nad sposobami, przez które ujawnia się świadomość językowa grup społecznych.

Badania nad świadomością językową są od lat tematem zainteresowania naukowców reprezentujących nie tylko typowe dziedziny językoznawstwa, takie jak socjolingwistyka czy psycholingwistyka, lecz także inne zakresy humanistyki, jak antropologia, socjologia i psychologia. Analizom badawczym poddaje się zazwyczaj materiały drukowane, przykładowo - np. teksty prasowe i książkowe, jak również materiały o charakterze ustnym, w tym - opinie użytkowników języka zebrane metodą wywiadów, dyskusji grupowych oraz rozmów, w których posłużono się pytaniami częściowo kierowanymi. 
Mimo wielu osiągnięć w tym zakresie dotychczas nie wypracowano na gruncie rodzimym względnie precyzyjnego akcesorium badawczego, według którego zgromadzony materiał językowy powinien podlegać analizie ${ }^{1}$. Niniejsza publikacja to próba opisu takich właśnie narzędzi oraz zależności zachodzących między nimi². Charakterystyka opiera się na dokonaniach Dennisa R. Prestona, który pierwszy zaproponował serię wyznaczników do badań socjolingwistycznych nad świadomością językową (Preston 1996; Niedzielski i Preston 2000).

Niniejszy artykuł ma na celu: 1) rekapitulację najważniejszych założeń badawczych Dennisa R. Prestona, 2) zilustrowanie relacji między wyróżnikami potocznej świadomości językowej, 3) postawienie wstępnej diagnozy dotyczącej przydatności tych wyznaczników w badaniach nad świadomością językową użytkowników polszczyzny. Do opisu koncepcji Dennisa R. Prestona posłużę się częściowo przykładami użytymi przez samego badacza ${ }^{3}$, a częściowo odwołam się do przykładów porównywalnych, ale pochodzących ze źródeł rodzimych. Są to polska literatura językoznawcza, bogata w egzemplifikacje, oraz własne materiały językowe, które od blisko dwóch dekad ekscerpuję wśród polskiej grupy etnicznej w Kanadzie. Do zbiorów należą nagrania rozmów prowadzonych z reprezentantami pokolenia imigracyjnego i polonijnego, komentarze i odpowiedzi do postów językowych publikowanych w zamkniętych grupach polonijnych na Facebooku ${ }^{4}$, a ponadto zbiory obserwacji zachowań językowych. Zastosowanie polskiej egzemplifikacji - która w każdym przypadku okazuje się porównywalna z oryginałem - służy eksplikacji omawianych zagadnień; jej celem nie jest dowiedzenie, że systematykę Dennisa R. Prestona cechuje uniwersalizm.

\section{UJĘCIA ŚWIADOMOŚCI JĘZYKOWEJ W JĘZYKOZNAWSTWIE POLSKIM}

W polskich naukach humanistycznych świadomość językowa jest pojęciem „nieostrym, dość różnie rozumianym przez uczonych" (Cygan 2002, 52), choć w ciągu ostatnich dziesięcioleci pojawiło się wiele rozważań odnośnie do tego fenomenu (np. Maćkowiak 2011, 2020; Miodunka 2017; Sagan-Bielawa 2014). W analizie tego zagadnienia badacze uwzględniają „,możliwości tworzenia nowych eksplikacji i poszukiwania kolejnych

\footnotetext{
${ }^{1}$ Novum stanowią badania zespołu Katarzyny Kłosińskiej, w których jasno wyznaczono wiele kodów jako narzędzi badawczych służących do analizy postaw wobec współczesnego języka polskiego i norm językowych (Kłosińska i in. 2017).

${ }^{2}$ Pierwsze ujęcie problemu wyznaczników potocznej świadomości językowej przedstawiono w: Lustański 2021.

${ }^{3}$ Niektóre egzemplifikacje użyte przez Dennisa R. Prestona mogą być w pewnym stopniu niezrozumiałe dla językoznawców niespecjalizujących się w lingwistyce angielskiej, np. gdy mowa o przemianach socjolingwistycznych zachodzących w mniej znanych odmianach języka angielskiego, jak np. African American Vernacular English (AAVE). Notabene autorka artykułu prowadziła przez kilka lat wykłady z socjolingwistyki na wydziale lingwistyki McMaster University w Kanadzie.

${ }^{4}$ Chodzi o następujące grupy: Polki w Kanadzie (139 komentarzy udzielonych przez 76 uczestniczek dyskusji); Polonia Kanada News (65 komentarzy autorstwa 57 osób); Polonia Edmonton News (17 komentarzy, 13 osób zabrało głos w dyskusji).
} 
obszarów zastosowania tego pojęcia w praktyce analitycznej” (Wojtak i Siwiec 1999; 45). Podstawowe źródła encyklopedyczne definiują świadomość językową jako „ogół poglądów jednej osoby, grupy społecznej lub szerszej zbiorowości na język, a także ogół postaw wobec niego i emocji z nim związanych". Swoim zakresem obejmuje:

1. Wiedzę o języku (intuicyjną, szkolną, rzadziej naukową); 2. Kompetencję językową, czyli zdolność do właściwej selekcji środków językowych, adekwatnych do celu wypowiedzi, jej charakteru, stylu, adresata; oraz 3. Ocenę ich akceptowalności fonetycznej, gramatycznej, logicznej, kulturowej itd., czyli poczucie językowe (Urbańczyk i Kucała 1999, 394).

Zdaniem Elżbiety Sękowskiej na fenomen świadomości językowej można patrzeć w trojaki sposób - z punktu widzenia psychologicznego, społecznego oraz praktycznego. Podejście psychologiczne pozwala zrównywać świadomość z wiedzą idealnego użytkownika języka, ergo pojmować ją jako synonim kompetencji językowej; w podejściu społecznym świadomość językowa stanowi składnik kompetencji komunikacyjnej; natomiast w podejściu praktycznym pojęcie świadomości językowej jest synonimem terminu sprawności językowej (Sękowska 1996, 9). Innego rodzaju stratyfikację buduje Krzysztof Maćkowiak (2011), według którego można wyróżnić pięć zakresów pojęcia świadomości językowej: normatywny, socjolingwistyczny, opisowo-rejestrujący, psycholingwistyczny i kulturowo-antropologiczny.

W polskiej socjolingwistyce wyszczególnia się ponadto warstwy świadomości językowej. Najlepiej znana jest stratyfikacja zaproponowana przez Andrzeja Markowskiego (2008a, 220-222). Badacz wyróżnił poziom 1) intuicji językowej, 2) sądów i opinii językowych, 3) znajomości kryteriów oceny danej cechy językowej. Poziom podstawowy bliski jest rozumieniu intuicji językowej, czyli subiektywnemu poczuciu użytkownika języka przy wyborze konkretnych form. W obrębie intuicji językowej mieszczą się zwykle elementy świadomości estetycznej, która przejawia się w używaniu często słyszanych, dość utartych wyrażeń, jak np. „brzmi obco” lub „razi mnie”. A zatem są to przekonania, które pojawiają się bez rozmyślnego operowania przesłankami i w których rozumowanie odbywa się bez uświadamiania sobie, w jaki sposób przebiega dochodzenie do rozwiązania problemu.

Wyższy poziom świadomości językowej przejawia się w wygłaszaniu ,sądów językowych, związanych z koniecznością wyboru między różnymi elementami językowymi i oceną tych elementów" (Markowski 2008b, 124). W tej warstwie świadomości użytkownik odwołuje się do podstawowej wiedzy o języku, którą zdobył w szkole (w rozumieniu takiego mówiącego, nauczyciel jest widziany jako autorytet w dziedzinie kultury języka), oraz do wiedzy nabytej w codziennej komunikacji zachodzącej między ludźmi zamieszkującymi określone terytorium geograficzne. Na poziomie sądów językowych wyróżnia się również postawy oparte na wiedzy zdroworozsądkowej, które sięgają do zasobów wiedzy potocznej, a nie - tylko do szkolnej wiedzy językowej (Dubisz 2017, 304).

Użytkownik języka reprezentujący najwyższy poziom świadomości językowej odwołuje się do znajomości jakiegoś kryterium oceny (np. uzusu). Swoje sądy językowe 
próbuje uzasadniać merytorycznie, np. gdy wybiera wyraz rodzimy zamiast obcego lub formułuje odpowiednią regułę w tym zakresie. Stanisław Gajda zauważa, że ,językowa samowiedza" istnieje w trzech płaszczyznach. Są to:

1) poczucie językowe — raczej intuicyjny ogląd praktyki komunikacyjnej i fragmentaryczne uświadomienie sobie niektórych jej stron; 2) potoczna świadomość językowa - znacznie wyższy stopień samowiedzy, mniej lub bardziej rozbudowanej, co zależy od wielu różnorodnych czynników; 3) naukowa wiedza o komunikacji językowej - wiedza nie pozbawiona luk, o różnym stopniu głębokości, uzyskana $\mathrm{w}$ toku procesu badawczego $\mathrm{w}$ wielu dyscyplinach, które zajmują się ludzkim porozumiewaniem się (m.in. lingwistyka, psycholingwistyka, teoria komunikacji, teoria tekstu, filozofia, semiotyka, naukoznawstwo) (Gajda 1994, 229).

Z perspektywy ogólnej można więc stwierdzić, że badacze socjolingwistyki polskiej ujmują świadomość językową jako wytwór ludzkiego rozumu, efekt życia w społeczeństwie czy też pewną postawę wobec czegoś. Badania nad tym fenomenem prowadzą często na pograniczu kultur i odmian języka, przefiltrowanego przez doświadczenie społeczne mówiących. W opracowaniach materiału typowe są nawiązania do świadomości społecznej i wartościowania kulturowego (zob. np. prace Haliny Kurek, Haliny Pelcowej, Stanisława Cygana, Mirosławy Sagan-Bielawy). Definicje świadomości językowej oraz jej stratyfikacje w rozumieniu Andrzeja Markowskiego i Stanisława Gajdy jako punkt wyjścia obierają klasyczne typy poznania przedmiotu, czyli intuicję i wiedzę (potoczną, szkolną, naukową). W tym artykule warto poświęcić trochę uwagi dwóm innym perspektywom badawczym, rzadko uwzględnianym w polskiej socjolingwistyce: 1) tzw. nosicielom świadomości językowej, czyli przeciętnym użytkownikom języka, oraz 2) wyróżnikom świadomości językowej jako takiej.

\section{ŚWIADOMOŚĆ JĘZYKOWA W LINGWISTYCE AMERYKAŃSKIEJ}

W badaniach prowadzonych w językoznawstwie zachodnioeuropejskim i amerykańskim pojęcie świadomości językowej jest terminem odnoszącym się głównie do językoznawstwa szkolnego, zwłaszcza do glottodydaktyki. Dictionary of Linguistics and Phonetics pod red. Davida Crystala (2001) definiuje to pojęcie w odniesieniu do takiej reakcji na użycie języka, która jest responsywna (w sensie 'wyczulona, nakierowana na język'), przemyślana oraz krytyczna. Częścią świadomości jest również uzmysławianie sobie istnienia terminologii językowej, czyli świadomość metajęzykowa ${ }^{5}$. Ronald Carter (2003) uważa, że świadomość językowa wiąże się z kształtowaniem wrażliwości na problemy językowe oraz z rozwijaniem w mówiących zdolności uprzytamniania sobie, w jaki sposób działają funkcje języka i jego formy. Badacz podkreśla - podobnie jak David Crystal - że pojęcie świadomość językowa okazuje się charakterystyczne dla

\footnotetext{
${ }^{5} \mathrm{~W}$ oryginale: „Language awareness: a term used especially in educational linguistics, to refer to an informed, sensitive and critical response to the use of language by oneself and others, including the awareness of relevant terminology ('metalinguistic awareness')" (Crystal 2001, 215).
} 
badań nad procesem akwizycji języka drugiego lub obcego, a w odniesieniu do języka rodzimego (pierwszego) preferuje się określenie wiedza o języku. Prace badawcze nad świadomością językową należą do dydaktyki wielojęzyczności, która stawia sobie za cel integrację uczniów posługujących się różnymi językami lub dialektami w kontekście pozalekcyjnym a także uświadamianie im wielojęzyczności społeczeństw (zob. Gębal 2013, 52-55).

W ostatnich trzech dziesięcioleciach pojęcie świadomości językowej zaczęto stosować w dziedzinie zwanej dialektologia percepcyjna, której zasadniczym zadaniem jest badanie, jak niefilolog (innymi słowy: laik) postrzega dialekty i zróżnicowanie dialektalne. Ten obszar socjolingwistyki amerykańskiej jest w Polsce mało znany (Stachowski 2018; Bounds 2015), chociaż daje interesujące możliwości eksploracji badawczej. W rozumieniu Dennisa R. Prestona, uznawanego za ojca dialektologii percepcyjnej, świadomość językowa to stopień uzmysłowienia sobie, jaki mają przeciętni użytkownicy języka w odniesieniu do niego ${ }^{6}$ (Preston 1996; Niedzielski i Preston 2000). To pojęcie Dennis R. Preston opatruje przymiotnikiem folk, który można tłumaczyć jako potoczny ${ }^{7}$. W powyższej definicji istotne jest wyróżnienie elementu nosicieli świadomości językowej ze względu na charakterystyczny dla nich punkt widzenia świadomości. Zasadnicza linia podziału przebiega między specjalistami językowymi (językoznawcami i specjalistami pokrewnych dziedzin, np. filologami) a niespecjalistami, których można określić mianem ,językoznawczych laików”. Laicy lub niespecjaliści to przeciętni użytkownicy języka, którzy nie mają wykształcenia lingwistycznego a ich świadomość językowa opiera się w zasadniczym stopniu na intuicji, samowiedzy oraz potocznej wiedzy o świecie ${ }^{8}$. W odniesieniu do specjalistów - ex definitione - poziom świadomości językowej staje się pogłębiony w wyniku zdobytej wiedzy naukowej o języku. Świadomość językową laika, a więc przeciętnego użytkownika języka, określam mianem potocznej ${ }^{9}$ świadomości językowej (folk-linguistic awareness).

\section{O WYMIARACH POTOCZNEJ ŚWIADOMOŚCI JĘZYKOWEJ}

Na bazie szeroko zakrojonych badań przeprowadzonych metodą ankiet oraz wywiadów środowiskowych Dennis R. Preston stworzył listę wyróżników potocznej świadomości językowej, na które składają się: 1. dostępność (availability), 2. trafność (accuracy), 3. szczegółowość (detail), oraz 4. umiejętność kontrolowania różnych wariantów języka (control).

\footnotetext{
${ }^{6} \mathrm{~W}$ oryginale: „I mean, by 'awareness', the 'degree' of consciousness non-linguists have in general about language" (Preston 1996, 72).

${ }^{7}$ Rozważania nad thumaczeniem określenia folk na francuski i niemiecki - zob. artykuł Paveau (2007).

${ }^{8}$ Próby rozróżniania - wśród nosicieli świadomości językowej - grup specjalistów oraz niespecjalistów podejmowano już wcześniej. Na gruncie lingwistyki polskiej po raz pierwszy wprowadził to rozróżnienie Jan Baudouin de Courtenay (1915).

${ }^{9}$ Krzysztof Maćkowiak (2020) wyróżnił dwie podstawowe odmiany świadomości: potoczną (spontaniczną, intuicyjną) oraz naukową (systematyczną, ocenianą w kategoriach prawdy lub fałszu).
} 


\section{Dostępność zakresu zjawisk językowych}

Jedynie pewne określone cechy językowe, lub fakty językowe, są dostępne świadomości przeciętnego użytkownika języka w tym samym stopniu. Dotyczy to zarówno performancji, kompetencji, a nawet reakcji na język. W kategorii dostępności Dennis R. Preston wyróżnia następujące składniki: a) elementy niedostępne, b) elementy dostępne, c) elementy poddające się sugestii oraz d) elementy typowe.

a) W grupie składników niedostępnych świadomości potocznej znajdują się specyficzne cechy fonologiczne, których laik językowy nie zauważa i nie komentuje. Przykładem może być wymowa pary wyrazowej [kop'e] (3 os. 1. poj. czasownika kopać) - [kop'e] (mianownik 1. mn. rzeczownika kopia). Nie ulega wątpliwości, że para tego typu jest niekiedy rozróżniana w wymowie pewnej grupy Polaków i percypowana jako odrębne formy (zob. Dunaj 1991), jednakże nielingwiści nie dyskutują na temat tego, czy [p'] to głoska miękka, czy też obecnie obowiązuje wymowa asynchroniczna, ergo czy system bez palatalnych fonemów wargowych trzeba uznać za dominujący w dzisiejszej polszczyźnie. Wiadomo również, że pewne określone cechy fonologiczne języka są obecne w świadomości przeciętnego mówiącego, lecz są niełatwo dostępne i wydobywane tylko wtedy, gdy badacz wskaże je laikowi i opisze. Za taką cechę należy uznać angielskie tzw. ciemne [1] (dark l) ${ }^{10}$, które jest wymawiane tak, że tylna część języka zostaje uniesiona w stronę velum, w wyniku czego tworzy zabarwienie zbliżone do polskiego scenicznego [1]. Nietrudno zauważyć, że nawet osoby władające biegle angielskim i polskim zwykle nie są świadome wpływu ciemnego [1] na wymowę polską, dopóki badacz nie wskaże im tej różnicy. Przykładowo: w nagraniach różnych odmian polszczyzny używanej w Kanadzie, które wykonywałam ze swoimi studentami, miałam do czynienia z osobami mówiącymi bardzo biegle po polsku, ale wymawiającymi słowa typu kowal, Jolka z angielska. Dopiero po odsłuchaniu nagrań i wskazaniu tej cechy fonetycznej, biorący udział w nagraniach zauważyli różnicę i kontrolowali wymowę podczas następnych prób nagraniowych.

b) Laik językowy może wypowiadać się na temat różnych problemów językowych wskazanych przez badacza, ale jeśli szczegóły omawianego zagadnienia nie są wprowadzone do rozmowy, przeciętny użytkownik języka raczej nie sięgnie do głębszych, dostępnych mu zasobów świadomości językowej. Ten fenomen ilustruje dyskusja w grupie facebookowej „Polki w Kanadzie”, gdzie w jednym z wielu wątków na temat polszczyzny używanej w Kraju Klonowego Liścia ${ }^{11}$ przeważająca liczba komentarzy dotyczyła leksyki (lub ogólnych spostrzeżeń o języku polskim), która znajduje się pod przemożnym wpływem angielszczyzny. Oto przykłady:

\footnotetext{
${ }^{10} \mathrm{~W}$ kanadyjskim angielskim ten alofon pojawia się w wygłosie oraz przed spółgłoską.

${ }^{11}$ Oto treść wątku: „Dziewczyny, usłyszałam niedawno takie zdanie: «Zastopował mnie kop i zaczardżował za speeding». Co myślicie o tym, jak mówią Polacy mieszkający w Kanadzie? Jakie są wasze opinie?".
} 
[29A] Ważne że rozumiem ... nie wierzę że tak mówią specjalnie ... to się poprostu miesza ... ja też tak czasem mówię .... czasem słowo mi poprostu nie pasuje $\rightarrow$ Np idę do bejsmentu wstawić pranie bo przecież nie do piewnicy hihi. ${ }^{12}$

[19A] To ja jeszcze dodam, mnie denerwuje jak oglądam telewizje z Polski i słyszę jak się używa słów pochodzących z angielskiego. Zgadzam się że są rzeczy pochodzące z Ameryki odnoszące się do specyficznych sprawy jak np komputerów ale „imidz” to mi strasznie nie pasuje. Chociaż....w języku polskim zawsze były słowa pochodzące $\mathrm{z}$ innych, np żydowskiego, łaciny, niemieckiego, czy francuskiego. Widocznie taka ewolucja.

c) Elementy podatne na sugestie uwidaczniają się w wątku, w którym jedna z internautek wypowiedziała się następująco: [47A] „To mój syn i jego polski”. Do komentarza dołączyła zrzut z ekranu telefonu następującej treści: „Auto nie jedzie, Co znim moze bycz? Olej byl Dolany? Bo dym leczi z szylnika", na co inna internautka zareagowała następująco:

[74D] Radzi sobie chłopak. Można zrozumieć. Moja córka też miesza języki albo zapomni słów. Któregoś dnia zapytała babcię: „babcia! Kiedy zdechła twoja mama”. Wtenczas nie znała słowa „umarła”. No cóż!

Nosiciel świadomości językowej po studiach filologicznych zauważy bez trudu, że w treści wiadomości SMS-owej nie ma mieszania języków ${ }^{13}$, za to pojawia się mieszanie zapisów graficznych szeregów spółgłosek zwarto-szczelinowych i szczelinowych z miękkimi: [č $]$ - [ćc, [̌̌s - [ś]. Internautka, która udzieliła odpowiedzi, została zwiedziona pozorną, ale ostrą wizualnie niepoprawnością ortograficzną. $Z$ tego powodu w komentarzu posłużyła się przykładem z zakresu leksyki i semantyki.

d) Poza elementami niedostępnymi, dostępnymi oraz poddającymi się sugestii istnieją jeszcze typowe cechy językowe, które dotyczą tego, co powszechne, znane mówiącemu z doświadczeń społeczno-kulturowych:

[07A] Czasem jest po prostu prościej wtrącić ang słówko zamiast polskiego. Łatwiej zapytać męża czy wykupił car insurance niż ubezpieczenie na samochód.

[73D] Słyszałam kiedyś rozmowę Hindusów a co jakiś czwarty wyraz był po angielsku... więc nie tylko my to robimy...więc czym się przejmować...normalka...

[65A] Osobiście mi to nie przeszkadza. Szybciej czasami jest wtrącić jakieś słowo po angielsku już po polsku bo tu mieszkamy i żyjemy...I tak wszyscy z nas to rozumieją. Ale faktycznie ...brzmi czasem śmiesznie.

Jednostki dostępne potocznej świadomości językowej przeciętnych użytkowników języka mają charakter stereotypowych, utartych i zbanalizowanych stwierdzeń

\footnotetext{
${ }^{12} \mathrm{~W}$ cytatach wprowadziłam korektę najbardziej ewidentnych usterek graficznych: usunęłam zbędne przerwy, poprawiłam literówki (np. prwda na prawda), zmieniłam użycia dużej litery I na oznaczenie spójnika $i$, wprowadziłam polskie znaki diakrytyczne, których gros uczestników polonijnych forów społecznościowych niestety nie stosuje. Błędy ortograficzne, słownikowe i interpunkcyjne zostawiłam w wersji oryginalnej.

${ }^{13}$ Można ewentualnie zauważyć pewną nienaturalność wyrażenia co z nim może być, które może być traktowane jako kalka składniowa angielskiej struktury what’s with something, ale ze względu na obecność zaimka nim wyrażającego zgodę rodzajową z podmiotem auto, a nie tym w zdaniu, można powiedzieć, że jest to eliptyczna forma wyrażenia co z nim może być [nie tak].
} 
odnoszących się do mowy imigrantów. Interlokutor może nimi sterować, gdyż poddają się one sugestii oraz emocjom panującym w konwersacji. Te cechy językowe są często powielane bezrefleksyjnie, przez co stanowią nierzadko usprawiedliwienie określonych zachowań o charakterze językowym.

\section{Stopień trafności}

Stereotypowe (lub potoczne) opisy języka, będące wyrazem świadomości językowej nielingwisty, mogą być trafne lub nie. W rozumieniu Dennisa R. Prestona trafność nie utożsamia się z poprawnością, gdyż ta druga zakłada wartościowanie. Trafność jest rozumiana jako odrębne pojęcie z zakresu tzw. lingwistyki potocznej (folk linguistics), w myśl której niespecjalista językowy postrzega i opisuje język swoimi sposobami. Używa do tego własnych, znanych sobie kategorii, które nie okazują się gorsze od kategorii ustalonych w językoznawstwie, lecz są po prostu inne. W stosunku do kryteriów poprawności językowej stają się bardziej lub mniej trafne. Opinie tego typu ilustrują to zjawisko w sposób następujący:

[73H] wtrącanie słówek angielskich to nie to samo co przekształcanie języka angielskiego inszura itp.

[137A] Mam też koleżankę, która urodziła się tutaj i tutaj mieszka całe życie i naprawdę mówi pięknie po polsku. Czasami nie zna polskiego słowa i wkłada angielskie ale nie tworzy nowych wyrazów.

[52A] W mowie - mogę jakoś przeżyć jak ktoś (albo ja :P) wtrąca angielskie słówka. Spolszczone wersje angielskich słów drażnią mnie mocno. Ale w pisowni... albo pisze po polsku, albo po angielsku - i nie ma przebacz, i wszelkiego rodzaju „kary” i „katyge” doprowadzają mnie do szału.

Takie komentarze dowodzą, że w melanżu jednostek leksykalnych dialektu polonijnego nielingwiści dostrzegają różnice między różnorodnymi elementami języka - w powyższych wypadkach między cytatami a wyrazami adaptowanymi - oraz że trafnie umieją zilustrować swoje opinie przykładem. Ostatni wpis zawiera celne spostrzeżenie, dotyczące istotnej różnicy między dwoma odmianami języka polonijnego: mówioną i pisaną. Wiadomo, że odmiana pisana jest z zasady bardziej zachowawcza, natomiast odmianę mówioną cechuje znaczny liberalizm w doborze środków językowych. Co więcej, nie ma skodyfikowanych reguł pisowniowych dla - tak powszechnych w mowie - jednostek języka polonijnego, a różne sposoby zapisu tych jednostek, czy to $\mathrm{w}$ druku, czy w zapisie wirtualnym na portalach społecznościowych, rażą obcością. Ciekawym przykładem jest rzeczownik cottage, którego pisownię polonizuje się następująco: katyge, kotycz, katycz, katydż.

Trafność sądów, którą odznacza się potoczna świadomość językowa, jest ściśle związana z doświadczeniem społecznym i kulturowym, które podlega wielu różnym czynnikom. Oto sprzeczne opinie o kanadyjskiej odmianie polszczyzny:

[15A] najczęściej mówią tak ci co niedawno tu przyjechali... ma to być pewnego rodzaju popisywanie się...

[18B] Ja kumam u ludzi, którzy długo mieszkają w Kanadzie i ang się posługują, No ale jak mi cwaniak z zerową znajomością angielskiego w rozmowie ze mną twierdzi, że on hedik ma, tam są kakrocie albo jak widzę tu pisane katycz to autentycznie grabki mi opadają. 
W opinii pierwszej uczestniczki dyskusji nasycenie języka jednostkami polonijnymi odnosi się do mowy osób niedawno przybyłych do Kanady, które próbują popisać się znajomością tutejszych obyczajów językowych i szybko dopasować się do nowej rzeczywistości. Druga internautka natomiast uznaje używanie dialektu polonijnego za usprawiedliwione, ale w odniesieniu do rodaków cechujących się długim stażem imigracyjnym, dla których ta odmiana polszczyzny stała się z biegiem lat środkiem codziennego porozumiewania się. Niełatwo ocenić trafność tych dwóch sądów, gdyż to, kiedy imigrant zaczyna przyswajać dialekt polonijny, zależy od wielu czynników, do których należą np. poziom wykształcenia, znajomość obu języków w kontakcie, związek emocjonalny z krajem pochodzenia, a nawet ogólna wrażliwość na język. Problem znajomości języka kraju osiedlenia porusza zresztą druga uczestniczka dyskusji, piętnująca snobizm językowy, który polega na wtrącaniu słów angielskich przez osoby słabo znające język angielski lub nieznających go prawie wcale.

A oto inna wypowiedź, która cechuje się częściową trafnością sądu językowego:

[12A] są wyrazy które zastępuję słowami angielskimi, a dotyczy to głównie słów mało popularnych, albo kompletnie nieistniejących, kiedy mieszkałam w Polsce.

Jest to stwierdzenie połowicznie słuszne, gdyż spora grupa leksemów polskich zostaje zastąpiona odpowiednikami angielskimi, jednakże z badań nad warstwami leksykalnymi języka polonijnego wynika, że chociaż adaptacje są niekiedy podyktowane koniecznością nazwania nowych desygnatów, to jednak czynnikami, które przeważają w procesie przejmowania anglicyzmów do języka rodzimego imigrantów (Sękowska 1994, 2008), są frekwencja oraz regularność zapożyczeń w tzw. centrach tematycznych.

\section{Poziom szczegółowości}

W klasyfikacji Dennisa R. Prestona kolejnym wyznacznikiem potocznej świadomości językowej jest szczegółowość. W świadomości niejęzykoznawcy element języka może być opisywany od ogółu do szczegółu lub odwrotnie. Wobec tego dużym poziomem ogólności odznaczają się następujące refleksje:

[64A] ja tez tak często mieszam dwa języki....przez jakiś czas starałam się hamować i uważać ale to jest silniejsze ode mnie.

[36A] Każdej z nas się zdarza połączyć angielski i polski w jedna sentencji.

Powyższe wypowiedzi to tylko ogólny komentarz do wątku na temat leksyki polonijnej, ale widać w nich wyraźnie, że ograniczają się one do stereotypowych, raczej powierzchownych, obserwacji o mieszaniu dwóch języków. Pobieżne refleksje snuje też inna uczestniczka forum, która porównuje sytuację języka polskiego w Polsce z sytuacją w Kanadzie:

[91A] Moja obserwacja: W Polsce zauważam więcej wtrąceń z języka angielskiego niż wśród Polonii kanadyjskiej. Widać to i słychać na co dzień w mediach, na ulicy, u małych dzieci i starców, w miastach 
i w najmniejszych zakątkach wiejskich... 35 lat temu język polski wśród Polonii był bardziej „,zanieczyszczony" naleciałościami z angielskiego niż ten używany przez rodaków w PL. Dzisiaj język polski w Polsce jest bardziej zniekształcony niż używany przez Polonię 35 lat temu.

Jednak zagadnienie szczegółowości każe również odnotować, że w świadomości potocznej nielingwisty istnieją poglądy językowe, które mimo wszystko charakteryzuje znaczny stopień uszczegółowienia. W swojej ocenie leksyki polonijnej jedna z uczestniczek dyskusji dość drobiazgowo objaśnia, podpierając się przykładami, że używanie określonych jednostek polonijnych zależy od typu współrozmówcy oraz od sytuacji komunikacyjnej, w której mówiący się znajdują:

[17E] Myślę, że to naprawdę zależy z kim rozmawiamy. Ja mogę powiedzieć do męża 'trafik' ale do obcej osoby powiem 'korek'. Tak samo jest z moimi dziećmi. Do nich mówię 'wyrzuć to do śmieci' a mężowi mówię, że ‘jutro jest garbage day' kiedy trzeba śmieci wystawić. Z kumpelami możemy sobie żartami mówić i nie ma w tym nic złego ${ }^{14}$.

Pewien stopień szczegółowości można zaobserwować także w poniższej wypowiedzi, która gani bezrefleksyjne używanie spolszczonych anglicyzmów:

[77A] Nagle zapomnieli, że można jeździć autostradą (a nie „hajłejem”), jeść krewetki (a nie „,szrimpy”) i wyrzucić śmieci do śmietnika (a nie ,garbicza”) :)

Na podstawie powyższych przykładów można wnioskować, że stopień szczegółowości w opisywaniu danej cechy językowej jest związany z poziomem świadomości językowej niefilologa. Im sprawniejsza umiejętność posługiwania się językiem (przykładowo - dwie powyższe wypowiedzi odznaczają się dość znaczną poprawnością gramatyczną i interpunkcyjną), bardziej rozwinięta sprawność porównywania i analizy języków oraz uzmysławiania sobie działań językowych warunkowanych sytuacyjnie i socjokulturowo, tym więcej szczegółów pojawia się w wyrażanej opinii.

\section{Umiejętność kontrolowania różnych wariantów języka}

Czwartym wymiarem potocznej świadomości językowej w taksonomii Dennisa R. Prestona jest umiejętność naśladowania lub kontrolowania różnych wariantów języka, a nawet - różnych języków. Zarówno w mówieniu o języku (czyli w świadomości metalingwistycznej), jak i w wykonaniu językowym (performancji) mówiący może (ale nie musi) kontrolować różne warianty języka będącego przedmiotem działań językowych. Laik językowy, który potrafi wyrażać się tylko ogólnie o jakimś innym języku, może mieć wyraźną zdolność imitowania danej odmiany języka. Członkinie grupy

\footnotetext{
${ }^{14}$ Powyższa wypowiedź jest znamienna, gdyż pokazuje również świadomość roli, jaką odgrywa matka, w kształtowaniu języka dziecka, u którego trzeba wykształcić poprawne wzorce językowe. Zdaniem Władysława Miodunki (2020) na świadomość językową najbardziej wypływają członkowie rodziny, a dopiero następnie - inni ludzie.
} 
facebookowej „Polki w Kanadzie” przedstawiają swoje umiejętności kontrolowania wariantów kodu polonijnego w taki sposób:

[44A] Będąc w Polsce staram się być bardziej polska, niż nasi rodacy... mimo to zdarzają się wpadki.....Dzwonię do firmy, pytam o właściciela...oświadczam, że wczoraj zostawiłam message .... na to pan miłym głosem „,szefa nie ma, ale ja mam klucz do jego pokoju i mogę sprawdzić czy to tam jest”.

[142A] Mieszkam 26 lat w Kanadzie a poza Polską prawie 30 lat. Jeżdżę co roku do Polski i żaden taksówkarz nie domyślił się nigdy że mieszkam poza Polską.

W powyższych refleksjach ujawniły się pewne strategie, których używają przeciętni mówiący po to, żeby kontrolować język. Takie osoby wyraźnie przyznają, że wkładają wysiłek w to, aby pilnować czystości języka polskiego podczas pobytu w Polsce, starają się unikać wpływów angielszczyzny, ponieważ nie chcą, aby rodacy nie zorientowali się, że rozmawiają z rodakiem, który żyje od dawna poza Polską. Oczywiście, do pewnego stopnia taka samokontrola językowa jest możliwa, chociaż ma również swoje ograniczenia, czego przykładem jest wypowiedź internautki dotycząca nierozważnego posłużenia się angielskim słowem message.

\section{RELACJE MIĘDZY WYZNACZNIKAMI POTOCZNEJ ŚWIADOMOŚCI JĘZYKOWEJ}

Wyznaczniki potocznej świadomości językowej mogą - choć nie jest to warunek sine qua non - wchodzić we wzajemne relacje. Te zależności można zilustrować schematem czterowymiarowym, w którym przerywane linie odnoszą się do względnej odrębności elementów:

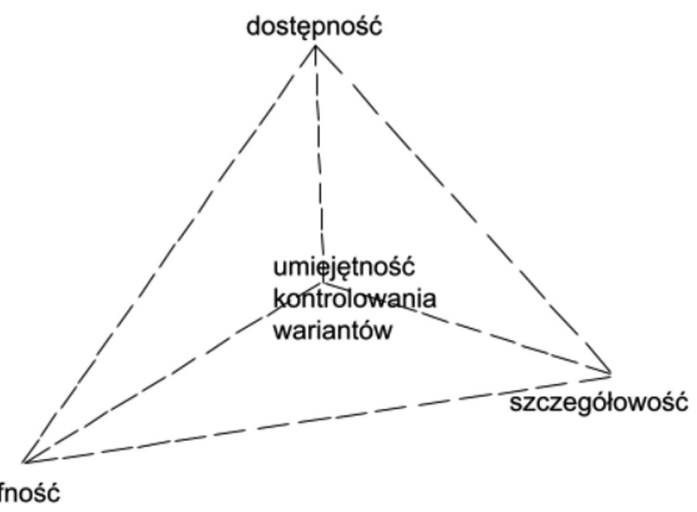

Rys. 1. Wyznaczniki potocznej świadomości językowej (rys. - J.L.)

Relacje między wyznacznikami mogą się kształtować następująco: dostępność trafność, dostępność - szczegółowość, dostępność - umiejętność kontrolowania wariantów, trafność -szczegółowość, trafność - umiejętność kontrolowania wariantów, szczegółowość - umiejętność kontrolowania wariantów. 


\section{Dostępność a trafność}

Relację między dostępnością a trafnością można scharakteryzować z wykorzystaniem anegdoty opisanej przez Leonarda Bloomfielda (1944), który zajmował się m.in. językami rdzennych Indian. Badacz opisał rozmowę z lekarzem, zdaniem którego język Chippewa zawiera tylko kilkaset słów. Ów lekarz, aby potwierdzić słuszność swoich założeń, przywołał opinię jakiegoś przewodnika pochodzącego z plemienia Chippewa. Słysząc to, Leonard Bloomfield próbował zaprzeczyć i wyjaśnić, że lekarz się myli, ale ten krótko i zdecydowanie powtórzył swoją opinię, a następnie odwrócił się plecami do językoznawcy ${ }^{15}$. Ta anegdotyczna historia pokazuje, że chociaż pojęcie języka Chippewa jest dostępne świadomości przeciętnego użytkownika języka i może je on komentować, to niespecjaliście językowemu brakuje trafnych i dokładnych, czyli akuratnych, wiadomości na temat tego języka. Innymi słowy: to, co lingwistyczny laik myśli, że wie o języku, może nie mieć potwierdzenia w wiedzy naukowej.

\section{Dostępność a szczegółowość}

Dennis R. Preston omawia względną niezależność między kategorią dostępności danej cechy językowej a kategorią szczegółowości jej opisu, a wykorzystuje do tego egzemplifikację rozmów o obcych akcentach. Dowodzi, że przeciętny użytkownik języka zazwyczaj dostrzega obcy akcent i często wyraża swoją opinię na jego temat, jednak gdy zostanie poproszony o przykład, zazwyczaj nie potrafi go przytoczyć. Również moje obserwacje językowe kilku różnych grup etnicznych w Kanadzie potwierdzają podobny fenomen w odniesieniu do francuskiego używanego w prowincji Quebec. Obiegowa opinia o tym typie francuszczyzny jest taka, że jest to odmiana niezrozumiała (lub zrozumiała w małym stopniu) dla mieszkańców Francji. W podobnym tonie wyraża się też jedna z uczestniczek dyskusji na forum grupy:

[137A] To jest też tak, z własnego doświadczenia w Quebec ludzie myślą, ze mówią po francusku, ale prawda jest taka, że Francuzi z Francji nie rozumieją francuskiego z Quebec.

Jej wypowiedź zripostowała inna internautka w sposób następujący:

[17D] Oni się swobodnie dogadają tylko québécois mówią językiem ‘luźnym’ i mają inny akcent. Moja córka w tym roku miała nauczyciela z francji i mówiła, że on mówił tak ładnie, bardziej formalnie. Ale rozumiała jego tak samo jak tutejszych nauczycieli.

A zatem przeciętny użytkownik języka z trudem wskazuje szczegóły, którymi charakteryzuje się kanadyjska odmiana francuskiego, chociaż można powiedzieć, że

\footnotetext{
${ }^{15}$ W oryginale: „A physician of good general background and education ... told me that the Chippewa language contains only a few hundred words. Upon question, he said that he got this information from his guide, a Chippewa Indian. When I tried to state the diagnostic setting, the physician, our host, briefly and with signs of displeasure repeated his statement and then turned his back on me" (Bloomfield 1944, 49).
} 
kanadyjski francuski jest dostępny świadomości mieszkańców Kanady, gdyż jest drugim językiem oficjalnym tego kraju.

\section{Dostępność a umiejętność kontrolowania wariantów}

Zależność między dostępnością a umiejętnością kontrolowania różnych wariantów języka można zilustrować przykładami mowy osób dwujęzycznych, które biegle władają dwoma językami.

[Studentka:] Byłam z mamą na takim...hmm...nie wiem, jak to powiedzieć po polsku, taki market, gdzie są stare rzeczy, nazywa się...jak takie małe zwierzę, insekt czy coś...

[Lektor:] Pchli targ?

[Studentka:] O tak! Pchli targ. Tam kupiłyśmy ten kubek do kawy.

Powyższy przykład jest fragmentem bardziej rozbudowanej wypowiedzi studentki uczącej się języka polskiego na poziomie zaawansowanym, która posługuje się polskim stosunkowo swobodnie. Zwykle dłuższe wypowiedzi osób biegle dwujęzycznych charakteryzują się obecnością operatorów metatekstowych typu ,jak to się mówi po polsku” albo ,jak to powiedzieć po polsku”. Ujawnia się w nich umiejętność kontrolowania języka przez mówiącego, który świadomie odrzuca użycie odpowiednika angielskiego w formie cytatu (w powyższym kontekście: flea market), a jednocześnie można zaobserwować, że dostępność odpowiedniego wyrażenia w jego umyśle jest w danym momencie w pewnym stopniu ograniczona.

Kategoria dostępności danej cechy językowej może być też niezależna od kategorii umiejętności przełączania między wariantami języka. Jakiś czas temu moje dziecko, wówczas sześcioletnie, które posługuje się sprawnie polskim i angielskim, przebywało w Polsce na wakacjach. Kiedy byliśmy z wizytą u przyjaciół, ich dzieci wielokrotnie prosiły moją córkę, mówiąc: ,,powiedz coś po angielsku”. Dziewczynka milczała, a po dłuższej chwili powiedziała: ,tu nikt tak [po angielsku - J.L.] nie mówi”. Można zatem stwierdzić, że w pewnych sytuacjach mówiący nie potrafią kontrolować wariantu językowego (ergo zmieniać go na żądanie), w którym są biegli, ponieważ kontekst, w którym proces ten zachodzi, może nie być odpowiedni ${ }^{16}$.

\footnotetext{
${ }^{16}$ Analogiczny przykład podaje Dennis R. Preston (1996, 42-43): „In some cases, respondents are not even able to control (i.e. perform on demand) a variety which they claim to be proficient speakers of because the setting or context is not right. After A claims to be a proficient speaker of African-American Vernacular English (AAVE) which her parents have claimed to have little or no knowledge of, her parents and the fieldworker coax her to give some examples, but she explains why it cannot be done, and her mother (R) elaborates:

R: So say something.

A: [ [No: I don- I can't really say any now cause I'm not among people who $=$

C: [[So say something yeah.

D: ( ) say something.

A: = speak, it just comes out ((laughs))".
} 


\section{Trafność a szczegółowość}

Zależność między trafnością a szczegółowością wiąże się z faktem, że opis cechy językowej, którego podejmuje się przeciętny użytkownik języka, może być ogólny lub dość szczegółowy i w każdym przypadku trafny lub nietrafny. Oto przykład takiej relacji, pochodzący ze środowiska polonijnego: podczas prób jednego z dziecięcych zespołów wokalnych w Toronto dyrektor zwraca dużą uwagę na wymowę chórzystów i często posługuje się wyrażeniem „nie sepleńcie”. Jego uwaga dotyczy typowej - dla mowy pokoleń polonijnych - zmiany w artykułowaniu spółgłosek szczelinowych i zwarto-szczelinowych, której przyczyną okazuje się brak fonemów palatalnych w języku angielskim. $Z$ językoznawczego punktu widzenia określanie tego fenomenu mianem „seplenienia" nie jest trafne, jednakże ów dyrektor potrafił precyzyjnie przedstawić, co ma na myśli, gdy zapytano go o to w prywatnej rozmowie. $\mathrm{Z}$ tego samego powodu nie można stwierdzić, że jest to określenie niepoprawne. Używanie terminu z zakresu zaburzeń mowy, czyli właśnie seplenienia, na oznaczenie tego typu interferencji nie ma jedynie charakteru anegdotycznego. Pojawia się w dyskusjach językowych między Polakami w Kanadzie, nawet w komentarzach facebookowych:

[75D] ja sama bardzo się staram mówić czysto po polsku, córka jeszcze bardziej (syn mniej ma okazji, ale mówi i bez seplenienia).

W opinii Dennisa R. Prestona analiza sposobu, w jaki przeciętni użytkownicy języka charakteryzują język, którego używają, jest bardzo istotna. Badacz podkreśla, że niespecjaliści językowi stosują do opisów swoje własne nazewnictwo, i zauważa, że to, co z punktu widzenia językoznawcy wydaje się niepoprawne, może być jedynie sprawą zwyczajnej niezgodności między słownictwem potocznym a specjalistycznym (trivial matter of labeling).

Przeciwny przykład pokazujący zależność między trafnością a szczegółowością można odnieść do wymowy przysłówków dzisiaj, tutaj realizowanej jako [žiśei], [tutei]. Wiele razy słyszałam, jak Polacy w Kanadzie pochodzący z rejonów miejskich $^{17}$ podejmowali próby szczegółowego objaśnienia, dlaczego taka wymowa jest wzorcowa. Ich zdaniem skoro mamy słowa tutejszy, dzisiejszy, to analogicznie powinniśmy mówić tutej, dzisiej, bo od przymiotnika odcinamy końcówkę-szy i w ten sposób powstaje forma przysłówka. Jak widać, mimo że można mówić o znacznej drobiazgowości w tłumaczeniu tego zjawiska językowego przez niespecjalistów, to mamy do czynienia z wyraźnym brakiem trafności naukowej z językoznawczego punktu widzenia.

\footnotetext{
${ }^{17}$ Formy typu tutej, dzisiej, wczorej są uznawane za regionalizmy mazowieckie - tak mówili m.in. inteligenci warszawscy. Zdaniem Bogusława Dunaja (1989) wymowa końcowego -aj jako [ei] jest charakterystyczna m.in. dla gwar miejskich.
} 


\section{Trafność a umiejętność kontrolowania wariantów}

W sprawie relacji między trafnością opisu cech językowych a umiejętnością kontrolowania wariantów warto nadmienić, że dany wariant języka może być powszechnie naśladowany w sposób mniej lub bardziej trafny. Jako przykład można podać mazurzenie, cechujące m.in. gwarę podhalańską. Niespecjalista językowy sądzi, że nie tylko

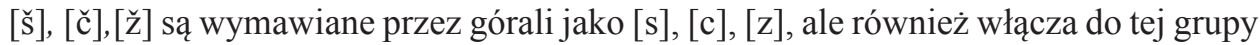
historyczne [r'] miękkie, czyli w zapisie $r z$, choć w wymowie - też [ž], które ma inną genezę i nie podlega mazurzeniu ${ }^{18}$.

Relację między trafnością a umiejętnością przełączania między wariantami języka dobrze ilustrują próby używania języka oficjalnego przez osoby nieprzywykłe do tego, które nie posługują się tą odmianą polszczyzny na co dzień. O ile mogą one pamiętać z czasów szkolnych, że wyrazy zakończone na -ika, -yka należy akcentować (wzorcowo) na trzecią sylabę od końca, np. muzyka, botanika, o tyle nie będą one pamiętać, że ta reguła dotyczy wyrazów pochodzenia łacińskiego. Per analogiam stosują więc akcent proparoksytoniczny w wymowie wyrazów rodzimych, np. bijatyka, pijatyka.

\section{Szczegółowość a umiejętność kontrolowania wariantów}

Zależność między kategorią szczegółowości a kategorią umiejętności kontrolowania wariantów polega na tym, że przeciętny użytkownik języka może mieć znaczną kontrolę nad szczegółami danego wariantu językowego, ale ten wariant może być mu dostępny jedynie w ogólnym zakresie. Wiele osób potrafi naśladować obcy akcent, na przykład „śpiewność” języka rosyjskiego lub polszczyzny kresowej, lecz nie umie wyjaśnić szczegółowo, na czym właściwie to zjawisko polega.

Powyższe kwalifikatory potocznej świadomości językowej mogą się formować w kontinua, ale z pewnym zastrzeżeniem, które wyraża Dennis R. Preston. Twierdzi on, że dostępność i umiejętność przełączania między wariantami mogą być również uważane za odrębne kategorie, natomiast stopień trafności i stopień szczegółowości można postrzegać jako zjawiska dychotomiczne. Tak czy inaczej, wszystkie charakteryzowane tu wymiary potoczności okazują się relatywnie względem siebie niezależne, a to znaczy, że usytuowanie refleksji na temat jakiejś cechy językowej na jednym z kontinuów nie warunkuje jej pozycji na innym. Jeżeli zdolność częściowej kontroli nad określonym wariantem językowym może odnosić się do spójności reprezentacji świadomości, a pozostałe wyznaczniki cechuje stopniowalność, to wyróżniki można przedstawić na następującym modelu:

\footnotetext{
${ }^{18}$ Przykładem mogą być różne wykonania pastorałki Oj, maluśki, maluśki, które słyszymy w kościołach.
} 


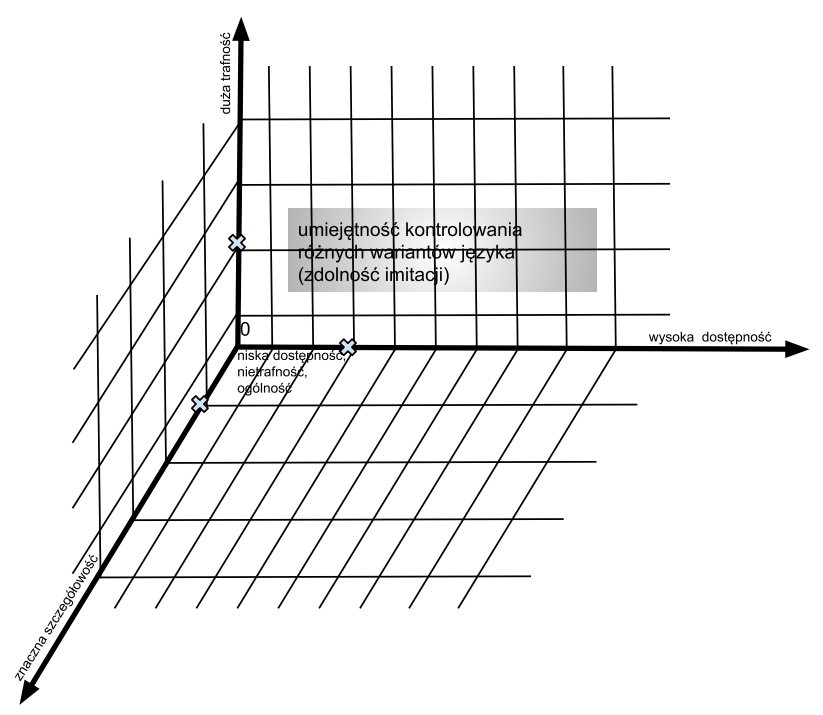

Rys. 2. Stopniowalność wyznaczników potocznej świadomości językowej (rys. - J.L.)

W przeciwieństwie do rys. 1 powyższy schemat nie pokazuje relacji między wyznacznikami potocznej świadomości językowej (np. szczegółowość jest względna wobec trafności), ale ilustruje stopniowalność poszczególnych elementów. Punkt „,0” ma jedynie charakter hipotetyczny, odnoszący się teoretycznie do wypadków skrajnych (np. klinicznych), gdy żaden poziom potocznej świadomości językowej nie jest mówiącemu dostępny. Świadomość językowa dotyczy przecież każdego użytkownika języka i nie możemy orzec, że ktoś, kto komentuje jakiś problem językowy, poddaje go refleksji, a nawet podejmuje jakąs językową aktywność, jest po prostu „nieświadomy”.

\section{WNIOSKI}

Wyznaczniki świadomości językowej pozwalają przyjrzeć się problemowi świadomości językowej z perspektywy innej niż dotychczas przyjęta w polskiej literaturze językoznawczej. W przedstawionych rozważaniach to, co nazywamy świadomością językową, nie ogranicza się do jednej grupy lub jednej klasy zachowań, np. postaw językowych (language attitude), lecz cechuje się wielowymiarowością. Mówiący, który potrafi ogólnie scharakteryzować jakąś odmianę języka, ma całkowitą (gross) kategoryzację różnic językowych dostępną swojej świadomości. Dzieje się tak, nawet jeśli językoznawca nie jest w stanie zmierzyć stopnia dokładności swoich obserwacji z powodu nieumiejętności produkcji językowej lub charakteryzowania szczegółów przez użytkownika języka.

Punkt widzenia na potoczną świadomość językową, proponowany przez Dennisa R. Prestona, ma naturę holistyczną, ponieważ koncentruje się nie na wyodrębnianiu perspektyw psychologicznych, społecznych czy kulturowych, ale na ogólnym założeniu, 
że świadomość językową stanowią zarówno kompetencja (językowa i komunikacyjna), jak i sprawność językowa. Można więc przyjąć, że potoczna świadomość językowa okazuje się nie tylko sprawą stopnia czy poziomu, na jakim użytkownik języka się znajduje (Bugajski 1999; Markowski 2008a), ale również sposobu (mode), w jaki wyraża on swoje opinie o języku. Tradycyjnie rozumiane warstwy świadomości językowej, czyli intuicja, wiedza szkolna lub zdroworozsądkowa (por. Dubisz 2017) oraz sądy uzasadniane merytorycznie, mogą być eksplikowane pod względem strategii, dzięki którym ujawnia się świadomość na poszczególnych piętrach. Przykłady użyte do zobrazowania techniki działania konkretnych narzędzi służących badaniu świadomości językowej pokazują, że jakiś ułamek świadomości ujawnia się w każdym akcie produkcji i percepcji językowej. Bez wątpienia jednak otwartym pytaniem pozostaje wciąż, jak precyzyjnie można mierzyć sposób i stopień uzewnętrzniania świadomości językowej.

Przeciętny użytkownik języka - zauważa en passant Dennis R. Preston - ma właściwą sobie, indywidualną świadomość językową o charakterze potocznym, która różnie ujawnia się w poszczególnych kontekstach. To, co przeciętny mówiący potrafi sobie uświadomić - jakie szczegóły mieszczą się w jego świadomości - zależy bardziej od faktów socjolingwistycznych niż od czysto lingwistycznych. Wbrew tej uwadze badacza trzeba jednak pamiętać, że czysto indywidualistyczne ujęcie świadomości językowej wiąże się z ryzykiem doprowadzenia do relatywizmu, który może skutkować niemożnością badania fenomenu. Dlatego wydaje się, że lista konkretnych narzędzi do analizy potocznej świadomości językowej, którą Dennis R. Preston proponuje, jest bardzo atrakcyjna. Warto by - przykładowo - poddać analizie jakieś większe ilości materiału językowego i sprawdzić, czy te narzędzia okażą się przydatne do badań nad sposobami, przez które ujawnia się świadomość językowa grup społecznych, skoro dotychczas znane akcesoria badawcze są dość zsubiektywizowane, a czasem tworzone przez językoznawców ad hoc.

Na zakończenie warto ponownie zauważyć, że w świetle lingwistyki potocznej, którą reprezentuje Dennis R. Preston, świadomość językowa to stopień uzmysłowienia lub uprzytomnienia sobie, jaki mają przeciętni użytkownicy języka w odniesieniu do niego. W przedstawionym ujęciu świadomości językowej nie neguje się tradycyjnego rozumienia tego fenomenu ani też dorobku naukowego w tym zakresie, ale poszukuje się odpowiedzi na pytanie, w jaki sposób mówiący rozeznają problemy językowe. Dennis R. Preston powtarza za Henrym Hoenigswaldem (1966), że istotne jest, aby wiedzieć nie tylko to, czym język jest i jak ludzie go używają, lecz także to, co o nim myślą. W tej dziedzinie lingwistyki zadaniem badacza jest analizowanie zmian w nazewnictwie, którym posługują się zarówno lingwiści, jak i nielingwiści, aby następnie zbudować z nich nie statyczny model potocznej wiedzy językowej, ale dynamiczny kontekst aktualnego użycia języka. Obiektem badawczym jest język, który znajduje się w centrum interakcji badacza z mówiącymi i odznacza się autotelicznością. Ma on niepodważalną wartość, ponieważ należy do zasadniczych spraw człowieka.

Określenie potoczna świadomość zostało użyte w książce Mirosławy Sagan-Bielawy pt. Dziedzictwo pozaborowe. Społeczna świadomość językowa (2014). Badaczka, 
charakteryzująca to pojęcie, postuluje, żeby świadomości potocznej nie odrzucać jako bezwartościowej, choć nie można jej uznać za pewnik naukowy. Skoro potoczna świadomość jest faktem, zadaniem językoznawcy jest ją zbadać, wytłumaczyć, a nawet wykorzystać. Dlatego też omówione tutaj wyznaczniki potocznej świadomości językowej mogłyby pomóc w realizacji tego postulatu również na gruncie nauki polskiej. Zbadanie świadomości językowej przy użyciu narzędzi proponowanych przez Dennisa R. Prestona stworzyłoby nowe możliwości wglądu nie tylko w zawartość świadomości językowej przeciętnego użytkownika języka oraz grup społecznych, lecz także w sposoby, w jakie ta świadomość się ujawnia.

\section{BIBLIOGRAFIA}

Baudouin de Courtenay, J. 1915. „Charakterystyka psychologiczna języka polskiego”. W Encyklopedya Polska, red. J. Łoś, J. Rozwadowski, A. Brückner, J. Baudouin de Courtenay, i T. Benni. T. 2, dz. 3, cz. 1. Kraków, 154-268.

Bloomfield, L. 1944. „Secondary and tertiary responses to language”. Language 20: 45-55.

Bounds, P. 2015. „Perceptual regions in Poland: An investigation of Poznań speech perceptions”. Journal of Linguistic Geography 3: 34-45.

Bugajski, R. 1999. Pół wieku kultury języka w Polsce (1945-1995). Warszawa: Wydawnictwo Naukowe PWN. Carter, R. 2003. „Language Awareness”. ELT Journal 57 (1): 64-65.

Crystal, D. 2001. A Dictionary of Linguistics and Phonetics, $4^{\text {th }}$ Edition. Oxford: Blackwell Publishers.

Cygan, S. 2002. „Zagadnienie świadomości językowej w literaturze językoznawczej”. Annales Academiae Paedagogicae Cracoviensis. Studia Linguistica 1: 47-57.

Dubisz, S. 2017. Językoznawcze studia polonistyczne (pisma wybrane, uzupetnione, zmienione). Warszawa: Wydział Polonistyki Uniwersytetu Warszawskiego.

Dunaj, B. 1989. Język mieszkańców Krakowa. Cz. 1: Zagadnienia teoretyczne, fonetyka, fleksja. Kraków: Uniwersytet Jagielloński.

Dunaj, B. 1991. „Dwa dyskusyjne problemy polskiej fonologii”. W Prace językoznawcze 19. Studia polonistyczne, red. A. Kowalska, i A. Wilkoń. Katowice: Wydawnictwo Uniwersytetu Śląskiego, 40-46.

Gajda, S. 1994. „O kulturze porozumiewania się w nauce”. W Polszczyzna a/i Polacy u schyłku XX w., red. K. Handke, i H. Dalewska-Greń. Warszawa: Towarzystwo Naukowe Warszawskie, 227-237.

Gębal, P.E. 2013. Modele kształcenia nauczycieli języków obcych w Polsce i w Niemczech. W stronę glottodydaktyki porównawczej. Kraków: Księgarnia Akademicka.

Hoenigswald, H. 1966. „A proposal for the study of folk-linguistics”. W Sociolinguistics. Proceedings of the UCLA Sociolinguistics Conference 1964, red. W. Bright. The Hague - Paris: Mouton \& CO, 16-26.

Kłosińska, K., A. Hącia, S. Mandes, M. Adamczyk, i K. Kiełpińska. 2017. Postawy wobec języka. Raport z badań przeprowadzonych w ramach programu Ministerstwa Kultury i Dziedzictwa Narodowego „Obserwatorium Kultury” 2016-2017. Warszawa: Ministerstwo Kultury i Dziedzictwa Narodowego.

Lustanski, J. 2021. „Jak można badać potoczną świadomość językową”. Poradnik Językowy 2: 58-75.

Maćkowiak, K. 2011. U źródet polskiej świadomości językowej (X-XV wiek). Poznań: Wydawnictwo Poznańskie. 
Maćkowiak, K. 2020. „Podstawowe problemy teorii świadomości językowej”. Poradnik Językowy 2: 29-45. Markowski, A. 2008a. Kultura języka polskiego. Warszawa: Państwowe Wydawnictwo Naukowe.

Markowski, A. 2008b. „Panel dyskusyjny: O świadomości językowej współczesnych Polaków”. W Polska polityka językowa w Unii Europejskiej, red. J. Warchala, i D. Krzyżyk. Katowice: Wydawnictwo Uniwersytetu Śląskiego, 219-243.

Miodunka, W. 2017. „O potrzebie opisu i kształtowania świadomości językowej współczesnych Polaków”. Język Polski 47 (3): 5-18.

Miodunka, W. 2020. „Kształtowanie się świadomości językowej rodzimego użytkownika polszczyzny. Studium przypadku”. W Język a Kultura, t. 28, red. A. Burzyńska-Kamieniecka. Wrocław: Wydawnictwo Uniwersytetu Wrocławskiego, 9-24.

Niedzielski, N., i D.R. Preston. 2000. Folk linguistics. Berlin - New York: Mouton de Gruyter.

Paveau, M. 2007. „Perceptual Norms in Folk Linguistics”. Langage et société 1 (119): 93-109.

Preston, D.R. 1996. „Whaddayaknow?: The Modes of Folk Linguistic Awareness”. Language Awareness 5 (1): 40-74.

Sagan-Bielawa, M. 2014. Dziedzictwo pozaborowe. Społeczna świadomość językowa Polaków w Drugiej Rzeczypospolitej. Kraków: Księgarnia Akademicka.

Sękowska, E. 1994. Język zbiorowości polonijnych w krajach anglojęzycznych. Zagadnienia leksykalno-stowotwórcze. Warszawa: Wydawnictwo Uniwersytetu Warszawskiego.

Sękowska, E. 1996. „Wstęp”. W Świadomość językowa - kompetencja-dydaktyka. Materiały ogólnopolskiej konferencji „Z badań nad kompetencją i świadomościa językowa dzieci i młodzieży”. Warszawa: Elipsa.

Stachowski, K. 2018. „Przyczynek do dialektologii percepcyjnej Polski: Szczecin”. Język Polski 1: 5-17.

Urbańczyk, S., i M. Kucała, red. 1999. Encyklopedia języka polskiego. Wrocław: Zakład Narodowy im. Ossolińskich.

Van Essen, A. 1997. „Language awareness and knowledge about language: An overview”. W Encyclopedia of Language and Education. Vol. 6: Knowledge About Language, red. L. van Lier, i D. Corson. Dordrecht: Kluwer Academic, 1-9.

Wojtak, M., i A. Siwiec. 1999. „Świadomość stylistyczna na tle wybranych składników jej kontekstu pojęciowego". W Mowa rozświetlona myślą. Świadomość normatywno-stylistyczna wspólczesnych Polaków, red. J. Miodek. Wrocław: Wydawnictwo Uniwersytetu Wrocławskiego, 45-57.

\title{
Modes of Folk-linguistic Awareness and Relationships between Them
}

Keywords: folk-linguistic awareness, modes of language awareness, folk linguistics, language attitudes, Polish Canadians.

\begin{abstract}
This article presents modes of folk-linguistic awareness as defined by Dennis R. Preston, who first introduced them to American folk linguistics in the 90. of the past century. These modes are as follows: overt availability of language phenomena that are being commented, the degree of the opinion's accuracy, the level of
\end{abstract}


the specificity of folk knowledge, and the ability to control language varieties. The essential feature of the modes is that - unlike typical linguistic awareness research tools that help to analyze the layers and levels of language awareness - they allow the study of the ways in which the linguistic awareness of the average language user, so-called language layman, is revealed. In Polish studies on linguistic awareness, these determinants have not been described and used, although they present new possibilities for research explication. In this article, the explanations of Dennis R. Preston's concept are partly based on the examples used by the researcher in his publications, and partly on comparable examples, but coming from Polish linguistic sources that include linguistic examples excerpted among the Polish ethnic group in Canada. The paper also presents the relationships between the modes of folk-linguistic awareness which are illustrated graphically. A preliminary diagnosis of the suitability of the characterized determinants in research on the linguistic awareness of Polish speakers invites in-depth studies to what extent these relatively objective tools may turn out to be useful in the analyses of the modes by which the linguistic awareness of social groups is revealed. 